\title{
POLAROGRAPHIC REDUCTION OF MALEIC ANHYDRIDE, MALEATE AND FUMERATE IN PYRIDINE*
}

\author{
R. Takahashi and P. J. Elving \\ University of Michigan, Ann Arbor, Michigan, U.S.A.
}

\begin{abstract}
Maleic and fumaric acids in pyridine show only the reduction behaviour of the pyridinium ion, which is produced when any Brensted acid of aqueous $\mathrm{pK}_{\mathrm{a}}$ less than $c a 9$ is dissolved in pyridine. The diethyl esters each show two one-electron waves, which pattern is characteristic for the electrochemical reduction of double bonds in proton-poor solvents. Maleic anhydride, which is a dihydrofuran, shows initially a single wave at a potential considerably more positive than the reduction potential of diethyl maleate; with time, a second maleic anhydride wave appears and grows at the expense of the first wave. The anhydride slowly reacts with the trace of moisture in the solvent to form maleic acid, which behaves as already indicated.

Résumé-Dans la pyridine les acides maléique et fumarique ne révèlent que le comportement réducteur de l'ion pyridinium, qui est produit quand un acide quelconque de Brønsted de $\mathrm{pK}_{\mathrm{a}}$ aqueux inférieur à environ 9 est dissout dans la pyridine. Les esters diêthyle accusent chacun deux vagues à un électron dont l'aspect est caractéristique de la réduction électrochimique des doubles liaisons dans des solvants pauvres en protons. L'anhydride maléique, qui est un dihydrofurane, manifeste initialement une seule vague à un potential considérablement plus positif que le potentiel de réduction du diéthyle maleate; au cours du temps une seconde vague de l'anhydride maléique apparaît et s'étend aux dépens de la première vague. L'anhydride réagit lentement avce une trace d'humidité dans le solvant pour former l'acide maléique, qui se comporte comme il l'a été indiqué déjà.
\end{abstract}

Zusammenfassung-Das Reduktionsverhalten der Lösungen von Maleinsäure und Fumarsäure in Pyridin ist allein dasjenige des Pyridiniumions, welches sich bei der Auflosüng einer beliebigen Brønsted-Säure mit einem $\mathrm{pK}_{\mathrm{a}}$ von weniger als $c a .9$ (in Wasser) bildet. Die Diäthylester beider Substanzen ergeben 2 Einelektronenstufen, was für die elektrochemische Reduktion einer Doppelbildung in einem protonenarmen Lösungsmittel charakteristisch ist. Maleinsäureanhydrid, welches ein Dihydrofuran darstellt, zeigt anfänglich eine einzelne Stufe bei einem gegenüber dem Reduktionspotential des Diäthylmaleats bedeutend positiverem Potential. Mit der Zeit jedoch erscheint eine zweite Stufe, welche auf Kosten der primären Stufe wächst: Das Anhydrid reagiert langsam mit den Wasserspuren im Lösungsmittel unter Bildung von Maleinsäure, welche sich wie oben erwähnt verhält.

\section{INTRODUCTION}

THE ELECTROCHEMICAL reduction of the maleate-fumerate system in aqueous solution has been extensively studied in the authors' laboratory, particularly in respect to the effect of $\mathrm{pH}^{1-3}$. Consequently, it seemed of interest to investigate the behaviour of the system in a markedly aprotic solvent such as pyridine. It was hoped that it might be possible to compare the ease of reduction of the double bonds in maleate and fumerate with that of the double bond in maleic anhydride, which constitutes a dihydrofurantype ring system. In spite of a slight complication due to reaction of the maleic anhydride with the residual trace of water in the pyridine, the latter objective was realized.

\section{EXPERIMENTAL TECHNIQUE}

The essential features of polarography with the dropping mercury electrode (dme) in pyridine have been described..$^{4,5}$

\section{Chemicals}

The maleic and fumaric acids and their diethyl esters were Eastman white label reagent grade chemicals; maleic anhydride was recrystallized by sublimation.

* Manuscript received 25 April 1966. 
Pyridine (Merck) was dried with Linde molecular sieves Type 4A. Lithium perchlorate (G. F. Smith Chemical Co.) was dried at $190^{\circ} \mathrm{C}$. Argon ${ }^{4}$ used for purging test solutions of oxygen was first passed successively through drying agent and solvent thermostated at the same temperature as that of the test solution. Triple distilled mercury was used for the dme and the mercury pool anode.

\section{Apparatus}

A Sargent Model XV Polarograph was used for recording polarograms.

Characteristics of the dme at a mercury height of $50 \mathrm{~cm}$ in the background solution $\left(0.1 \mathrm{M} \mathrm{LiClO}_{4}\right.$ in pyridine) at open circuit were $m=1.20 \mathrm{mg} / \mathrm{s}$ and $t=4.11 \mathrm{~s}$.

A jacketed H-type cell (thermostated at $25^{\circ} \mathrm{C}$ ) was used, one compartment of which contained the test solution and the dme, while the other contained the background solution and mercury-pool anode, which served as reference electrode. The liquid junction between the two compartments was made by a coarse fritted glass disk and a plug of $5 \%$ methyl cellulose gel in pyridine saturated with $\mathrm{LiClO}_{4}$.

The potentials of the mercury-pool anode before and after polarographic runs were measured with reference to the silver electrode, $\mathrm{Ag} / \mathrm{AgNO}_{3}, 1 \mathrm{M}$, in pyridine, ${ }^{4-6}$ which itself has a potential of $+0.09 \mathrm{~V}$ (sce). 4 The pool potentials varied between 0.00 and $+0.01 \mathrm{~V}$ vs the silver electrode, in agreement with the statement ${ }^{6}$ that the potentials obtained $v s$ mercury pool in the same background solution are nearly equal to those obtained $v s$ the silver electrode.

Repeated measurements of the cell resistance of background solutions indicated this to be $2 \mathrm{~K} \Omega$ at most, which would result in $i R$ drops of a few $\mathrm{mV}$ for the currents involved in the present study.

\section{Procedure}

Suitable test solutions in pyridine of each of the maleate and fumarate species studied were prepared by standard techniques. After transference of the test solution to the cell, argon was bubbled through the solution for $15 \mathrm{~min}$ through a gas-dispersion tube and then the dme was inserted.

During the study of maleic anhydride, in order to minimize its hydrolysis, a known volume of background solution was first deoxygenated in the test solution compartment and then a known amount of the crystalline anhydride was added and dissolved.

Argon was kept flowing over the solution during the insertion of the dme and the succeeding polarographic run, in which the potential of the dme was scanned from $0 \mathrm{~V}$ vs the mercury pool in contact with $0.1 \mathrm{M} \mathrm{LiClO}_{4}$ solution in pyridine to the negative value at which the background discharge occurred.

The decomposition potential of the background solution, ie the potential at which the current reaches a magnitude of $1 \mu \mathrm{A}$, was $-1.9 \mathrm{~V} v s$ the pool.

\section{RESULTS AND DISCUSSION}

Table 1 summarizes the data obtained for the acids and their diethyl esters; Table 2 gives typical data for maleic anhydride.

\section{Background}

The small (ca $0 \cdot 2 \mu \mathrm{A})$ background wave (Table 1 ) at $-1 \cdot 70 \mathrm{~V}$, previously described ${ }^{5}$, may be caused by a pyridine analogue in the solvent; it shifted slightly to more 
Table 1. Polarographic Reduction of maleate and fumerate species In PYRIDINE

Background: $0.1 \mathrm{M} \mathrm{LiClO}_{4}$. Temperature: $25^{\circ} \mathrm{C}$. Concentration of electroactive species: $0.25 \mathrm{mM}$. Reference electrode: mercury pool.

\begin{tabular}{lcccccc}
\hline & \multicolumn{2}{c}{ Wave I } & \multicolumn{2}{c}{ Wave II } & \multicolumn{2}{c}{ Wave III } \\
\cline { 2 - 7 } & $E_{1 / 2}$ & $i_{l}$ & $E_{1 / 2}$ & $i_{l}$ & $E_{1 / 2}$ & $i_{l}$ \\
Compound & $\mathrm{V}$ & $\mu \mathrm{A}$ & $\mathrm{V}$ & $\mu \mathrm{A}$ & $\mathrm{V}$ & $\mu \mathrm{A}$ \\
(Background) & & & & & -1.70 & 0.20 \\
Maleic acid & -1.10 & 0.21 & -1.30 & 1.09 & & \\
Fumaric acid & -1.12 & 0.22 & -1.33 & 1.10 & & \\
Diethyl maleate & -1.16 & 0.57 & -1.35 & 0.57 & -1.70 & 0.21 \\
Diethyl fumerate & -1.25 & 0.72 & -1.43 & 0.54 & -1.70 & 0.20 \\
\hline
\end{tabular}

Table 2. Polarographic Reduction of maleic anHydride in PYRIDINE Background: $0 \cdot 1 \mathrm{M} \mathrm{LiClO}_{4}$. Temperature: $25^{\circ} \mathrm{C}$. Concentration of electroactive species: $1.3 \mathrm{mM}$. Reference electrode: mercury pool.

\begin{tabular}{ccccccccc}
\hline & \multicolumn{2}{c}{ Wave I } & \multicolumn{2}{c}{ Wave II } & \multicolumn{2}{c}{ Wave III } & \multicolumn{2}{c}{ Wave IV } \\
\cline { 2 - 8 } Time* & $E_{1 / 2}$ & $i_{l}$ & $E_{1 / 2}$ & $i_{l}$ & $E_{1 / 2}$ & $i_{l}$ & $E_{1 / 2}$ & $i_{l}$ \\
$\min$ & $\mathrm{V}$ & $\mu \mathrm{A}$ & $\mathrm{V}$ & $\mu \mathrm{A}$ & $\mathrm{V}$ & $\mu \mathrm{A}$ & $\mathrm{V}$ & $\mu \mathrm{A}$ \\
10 & -0.71 & 5.34 & & & -1.13 & 0.38 & -1.33 & 0.96 \\
40 & -0.70 & 3.92 & -0.87 & 0.72 & -1.13 & 0.56 & -1.32 & 1.44 \\
100 & -0.72 & 1.84 & -0.87 & 1.26 & maximum & \multicolumn{2}{c}{ maximum } \\
& & & & & & \multicolumn{2}{c}{$i_{l}=3.86$} \\
\hline
\end{tabular}

* Time elapsed from the dissolution of the maleic anhydride in pyridine.

positive potential on increasing the $\mathrm{LiClO}_{4}$ concentration, and gave a maximum current when a small amount (1-2\%) of water was added. When a small amount of acid, $e g$ benzoic or maleic acid, was added, the background wave decreased, while a new wave appeared at $-1.10 \mathrm{~V}$ and grew to a limiting height of about $0.2 \mu \mathrm{A}$, at which point the $-1.70 \mathrm{~V}$ wave disappeared.

\section{Maleic and fumaric acids}

Maleic acid and fumaric acid behave essentially identically in pyridine solution. The height of wave $I$ is constant for both acids in the concentration range of $0 \cdot 25$ $1 \mathrm{mM}$, but the sum of waves I and II is strictly proportional to the acid concentration. Both waves show a maximum when the acid concentration exceeds $0.3 \mathrm{mM}$. (Maleic and fumaric acids in concentrations exceeding $2 \mathrm{mM}$ give white colloidal precipitates in pyridine containing $0 \cdot 1 \mathrm{M} \mathrm{LiClO}_{4}$.)

The current behaviour and the numerical values of the half-wave potentials indicate that the waves are not caused by reduction of the double bond in the acids, but by the reduction of the pyridinium ion generated on dissolution of the acids in pyridine, with wave I being related to the background wave as described above and elsewhere ${ }^{5}$. The diffusion current constant data (3.63 for the sum of the two maleic acid waves and 3.69 for the fumaric acid waves) show that the total wave corresponds to a two-electron reduction, as would result from the two protons of each dibasic acid equally reacting with pyridine to form pyridinium ions, since the reduction of the pyridinium ion in pyridine is a one-electron process ${ }^{5}$. The double bond in pyridinium maleate and fumerate or in the corresponding anions is apparently not reduced within the available potential range; this is not unexpected in view of the increasing 
difficulty of reducing the anions in aqueous solution as the solution is depleted in available protons, ie with increasing $\mathrm{pH}^{., 3}$

Diethyl maleate and diethyl fumarate each give three reduction waves in pyridine. Wave III is independent of the ester concentration and is coincident with the background wave in both half-wave potential and wave-height; obviously, wave III is the background wave, which remains unchanged in the medium when acid protons from Brønsted acids are not added. Waves I and II can then be regarded as waves originating from the reduction of each ester. Since diethyl succinate does not give any reduction wave in pyridine, the two waves can be attributed to reduction of the carbon-carbon double bond. In each case, waves I and II are nearly equal in height, with each wave corresponding to a one-electron reduction process on the basis of the diffusion current constant values, which are 1.59 for each of the two diethyl maleate waves, and 2.01 and 1.52 for the diethyl fumerate waves.

The behaviour of the esters in giving two one-electron waves in pyridine for the over-all two-electron reduction of the carbon-carbon double bond is typical of the reduction of that bond and other double bond systems in proton-poor media, whereas the two one-electron processes coalesce in proton-available media, eg aqueous solution, to give a single two-electron wave ( $c f$ general discussion of possible mechanism paths for the two situations and the application to reduction of the carbon-carbon double bond in the phenyl-substituted ethenes). ${ }^{7,8}$

\section{Maleic anhydride}

Maleic anhydride gives a seemingly complex wave pattern in pyridine solution, which changes with time (Table 2). However, examination of the pattern on the basis of the behaviour of the background and of maleic acid (Table 1) clarifies the situation and allows unequivocal assignment of the waves due to reduction of the double bond in maleic anhydride.

Wave I (Table 2) represents the main reduction wave of maleic anhydride and would presumably be the only wave initially observed in pyridine solution. Wave II only appears about $30 \mathrm{~min}$ after the dissolution of the maleic anhydride and grows in height at the expense of wave I. Waves III and IV coincide with the waves observed when maleic acid is dissolved in pyridine. The sum of the heights of waves I and II decreases with time, while that of waves III and IV increases; the total wave-height, however, remains essentially constant at $6.64-6.96 \mu \mathrm{A}$, which is equivalent to a diffusion-current constant of $3 \cdot 57-3 \cdot 74$, which corresponds to that for a two-electron reduction.

The wave pattern behaviour is explicable on the basis of the occurrence of the moderately slow reaction of maleic anhydride with a trace of water present in the solvent to generate maleic acid,

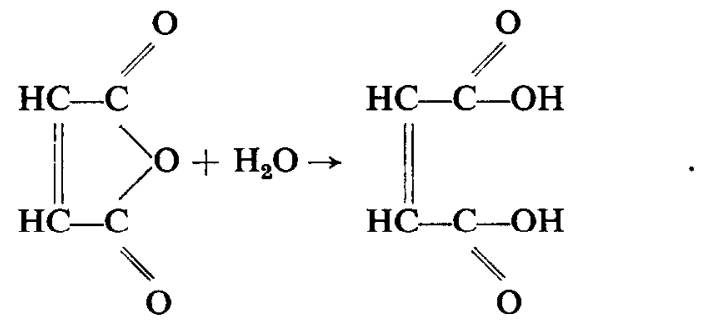


Each $0.01 \mathrm{wt}$ \% of water in the pyridine corresponds to a $5.4 \mathrm{mM}$ water concentration. The presence of water in large amounts, eg up to $10 \%$ by volume, does not affect the pyridinium ion reduction. ${ }^{6}$

The cause of wave II, ie the species whose reduction gives rise to the wave, is not yet known. However, the facts that the ratio of the heights of wave II to wave I increases with time and that the pyridine solution of maleic anhydride gradually turns yellow in about $1 \mathrm{~h}$, indicate that the reducible species is probably a reaction product of maleic anhydride with pyridine. This is supported by the fact that maleic anhydride reacts sufficiently rapidly with aniline to make titrimetric determination possible. Since pyridine is a weaker base than aniline, it would be expected to react more slowly with maleic anhydride.

The impressive fact is the large difference between the potentials of the initial reductions of maleic anhydride $(-0.70 \mathrm{~V})$ and of diethyl maleate $(-1.16 \mathrm{~V})$. In aqueous solution, the ester is much more readily reduced than the acid in either its protonated or anionic forms, eg at $\mathrm{pH} 10 E_{1 / 2}$ is $-1.04 \mathrm{~V}$ for the ester and -1.42 for the acid. ${ }^{3}$ It is evident that the effect of conjugation in the anhydride is considerably greater than in the ester.

Acknowledgement-The authors thank the U.S. Atomic Energy Commission and the Petroleum Research Fund of the American Chemical Society, which helped support the work described.

\section{REFERENCES}

1. P. J. Elving, Pure appl. Chem. 7, 423 (1963).

2. P. J. Elving and I. Rosenthal, Analyt. Chem. 26, 1454 (1954).

3. P. J. Elving and C. Tertelbaum, J. Am. chem. Soc. 71, 3916 (1949).

4. A. CisaK and P. J. Elving, J. electrochem. Soc. 110, 160 (1963).

5. M. S. Spritzer, J. M. Costa and P. J. Elving, Analyt. Chem. 37, 211 (1965).

6. L. Floch, M. S. Spritzer and P. J. Elving, Analyt. Chem. 38, 1074 (1966).

7. P. G. GrodzKa and P. J. Elving, J. electrochem. Soc. 110, 225 (1963).

8. P. G. GrodzKa and P. J. Elving, J. electrochem. Soc. 110, 231 (1963). 